OPEN ACCESS

Edited by:

Yuwei Li,

Liaoning University, China

Reviewed by: Lei Gong,

Northeast Petroleum University, China Lingyun Kong,

University of North Dakota, United States

Kouqi Liu,

Central Michigan University, United States

*Correspondence: Zhaosheng Wang zhaoshengw@126.com

Specialty section: This article was submitted to

Economic Geology,

a section of the journal

Frontiers in Earth Science

Received: 01 June 2021

Accepted: 19 July 2021 Published: 01 September 2021

Citation:

Wang Z, Muhtar M, Xu D, Fang J, Li J, Liu D, Zhang $Z$ and Gao L (2021) Seepage Behavior of Fractures in Paleogene Sandstone Reservoirs in Nanpu Sag, Bohai Bay Basin,

Eastern China.

Front. Earth Sci. 9:718733. doi: 10.3389/feart.2021.718733

\section{Seepage Behavior of Fractures in Paleogene Sandstone Reservoirs in Nanpu Sag, Bohai Bay Basin, Eastern China}

\author{
Zhaosheng Wang ${ }^{1,2 *}$, Meiri Muhtar ${ }^{3}$, Donghao $\mathrm{Xu}^{3}$, Jinchuan Fang ${ }^{3}$, Jing $\mathrm{Li}^{3}$, Daojie Liu ${ }^{4}$, \\ Zhenguo Zhang ${ }^{1}$ and Lianfeng Gao ${ }^{1}$
}

${ }^{1}$ College of Mining Engineering, Liaoning Technical University, Fuxin, China, ${ }^{2}$ College of Mining Engineering, North China University of Science and Technology, Tangshan, China, ${ }^{3}$ CNPC Logging Company Limited Xinjiang Branch, Karamay, China, ${ }^{4}$ CNPC Jidong Oilfield, Tangshan, China

Natural fractures play an important role in the seepage system of Paleogene sandstone reservoirs at Nanpu Sag. Characteristics and formation mechanisms of natural fractures and stress-sensitivity permeability are comprehensively investigated and their impact on water injection is discussed based on core and log data (FMl and diplog data) as well as stress-sensitivity permeability measurement. Results show that high-angle shear fractures, including NE-SW strike fractures and NW-SE strike fractures, are widely developed in the study area, which were primarily developed during the late Paleogene and late Neogene. The present maximum horizontal principal stress is orientated at $\mathrm{N} 60^{\circ}-80^{\circ} \mathrm{E}$, approximately parallel to the NE-SW fractures, contributing greatly to the seepage system at the early oilfield development stage. Fractures in the study area can be divided into three phases and are characterized by obvious stress-sensitivity permeability, which is closely related to fracture aperture and throat size. Since the fracture occurrence enhances stress sensitivity of permeability, it is necessary to regulate well pattern based on dynamic behaviors of fractured reservoirs at different development stages.

Keywords: fracture, formation mechanism, stress-sensitivity permeability, sandstone reservoirs, Nanpu sag

\section{INTRODUCTION}

As oil and gas resource consumption continuously increases, identifying and producing reserves from wide-distributed low-permeability reservoirs has attracted increasing attention (Shanley and Cluff, 2015; Alhuraishawy et al., 2018; Qing et al., 2021). Sandstone reservoirs with permeability $<50$ $\times 10^{-3} \mu \mathrm{m}^{2}$ are defined as low-permeability reservoirs in China (Zeng et al., 2013). They are commonly compacted with intensive brittleness, which is beneficial for the development of fractured reservoirs under strong diagenesis and tectonic activities (Tamagawa and Pollard, 2008; Olorode et al., 2012; Nagel et al., 2013; Cao et al., 2020). Fractures with porosity are commonly less than $0.5 \%$ and generally contribute little to the storage capacity of low-permeability reservoirs (Zeng et al., 2016; Lin et al., 2020; Liu et al., 2020). However, they can improve permeability significantly and bring strong heterogeneity (Laubach et al., 2018; Wang Z. S. et al., 2020; Gong et al., 2021). Pressure drops can commonly induce stress sensitivity of fractures, sharply close fractures around wells, and significantly decrease permeability, exerting a negative impact on oil and gas development (Li et al., 


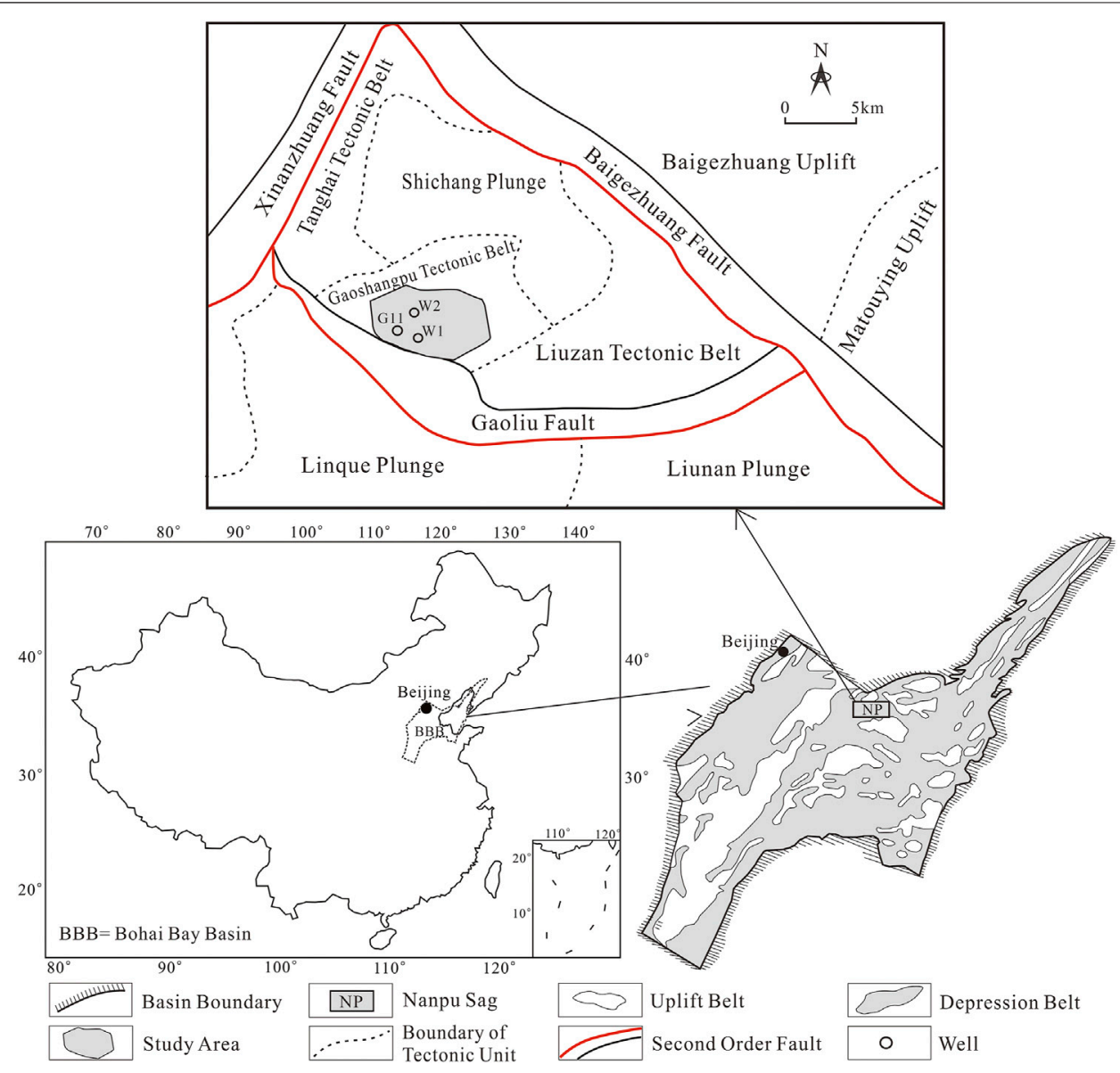

FIGURE 1 | Structure units and location of Nanpu Sag.

2021). Geologists and petroleum engineers are currently interested in fracture development in low permeability reservoirs, especially the variation of stress sensitivity of fractures, since fracture behaviors in low-permeability reservoirs is of great importance to improve production performance and enhance oil recovery (Khair et al., 2015; Babadagli, 2020; Zhang et al., 2021).

Nanpu Sag in Bohai Bay Basin has abundant hydrocarbon resources, while the latest oil and gas resource assessment shows that oil and gas resources are higher than $70 \times 10^{8}$ bbls (Jiang et al., 2018). The Gaoshangpu Oilfield at Nanpu Sag has not been well developed since being discovered in the late 1990s, even after a series of research and development deployments have been carried out. Specifically, production capacity was high at the initial stage with an average well yield of $371 \mathrm{bbls} /$ day but declined fast at the later stage, e.g., it decreased to a low value with high water injection pressure after water injection. Continuous pressure boosting increased the water cut greatly, exhibiting the typical production behavior of fractured reservoirs (Zeng et al., 2012; Gong et al., 2019a). The current recovery rate and average well yield are only $8.1 \%$ and $13.3 \mathrm{bbls} /$ day, respectively, whereas the water cut is up to $91.6 \%$. The following problems, e.g., 1) insufficient understanding of natural fracture development, 2) poor investigation on stress sensitivity of natural fractures, and 3) uncertainty about the impact of natural fractures on the water injection, limit the efficient development of Gaoshangpu Oilfield at Nanpu Sag.

In this paper, taking the Paleogene Shahejie low-permeability sandstone reservoir in Gaoshangpu Oilfield, Nanpu Sag, as an example, we investigate the genetic mechanisms and growth features of natural fractures, and discuss their stress sensitivity as well as their influence on water injection through integrating core data, log data, and a stress-sensitivity permeability experiment.

\section{GEOLOGICAL SETTING}

\section{Location and Structure}

Nanpu Sag in Bohai Bay Basin, Eastern China (Figure 1), is a Meso Cenozoic rift basin with an area of $1932 \mathrm{~km}^{2}$ (Pang et al., 2019). It is structurally characterized by faults in the east and north and overlaps in the west and south (Dong et al., 2010; Zhao et al., 2020). This study focuses on the Paleogene sandstone reservoir at Gaoshangpu Oilfield. This oilfield is located at the Gaoliu structural belt (on the upthrow of Gaoliu fault) in the 


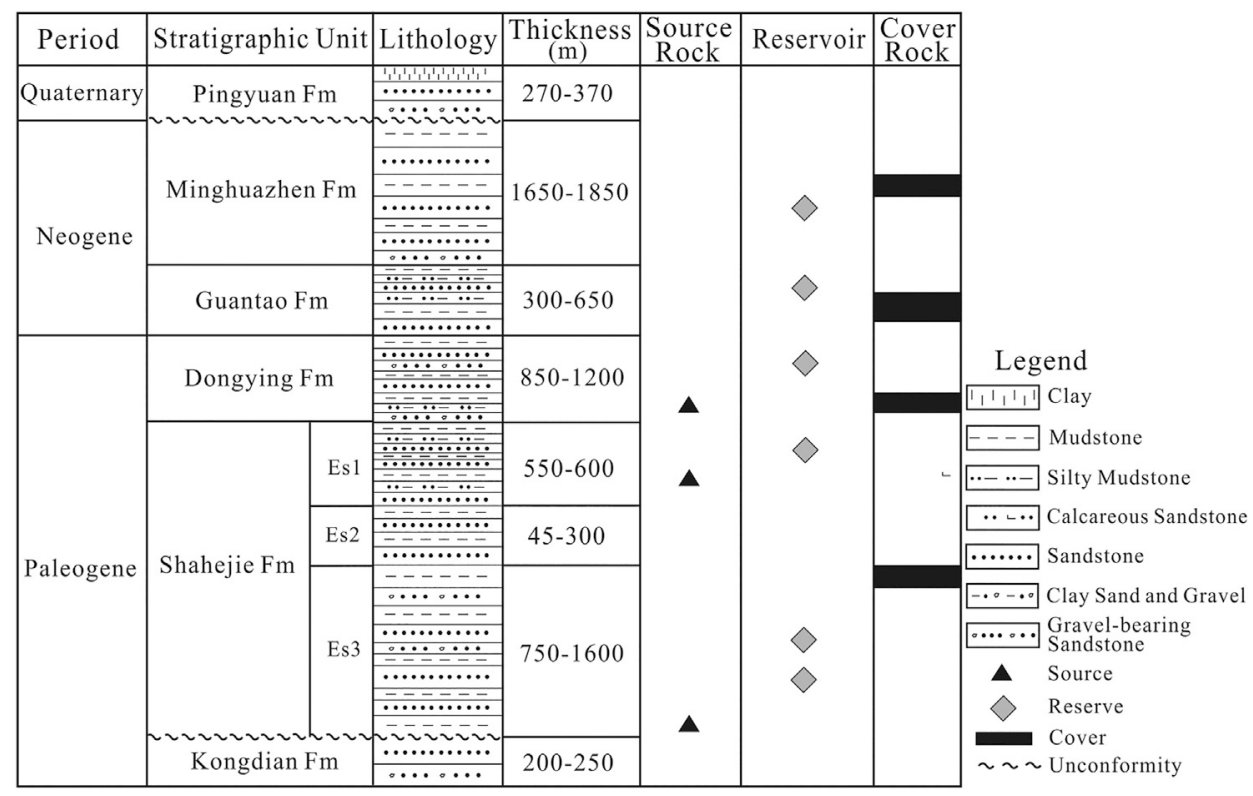

FIGURE 2 | The composite columnar section in Nanpu Sag.

north of Nanpu Sag, which is dominated by NE-SW, NW-SE, and near E-W faults, with an average length of $2.1 \mathrm{~km}$ and an average displacement of $100 \mathrm{~m}$.

\section{Stratum}

The strata drilled in Gaoshangpu Oilfield are Paleogene Shahejie Formation (Es) and Dongying Formation (Ed), Neogene Guantao Formation $(\mathrm{Ng})$ and Minghuazhen Formation $(\mathrm{Nm})$, and
Quaternary Pingyuan Formation from bottom to top (Zhang et al., 2018). Shahejie Formation uncomfortably connects with Kongdian Formation, and Quaternary Pingyuan Formation is in unconformity contact with Neogene Minghuazhen Formation (Figure 2). The Paleogene Shahejie Formation is one of the primary oil-bearing intervals at Nanpu Sag, which can be divided into Sha-3 Member $\left(\mathrm{E}_{\mathrm{S}}{ }^{3}\right)$, Sha-2 Member, and Sha-1 Member from bottom to top. The Sha-3 Member is the most

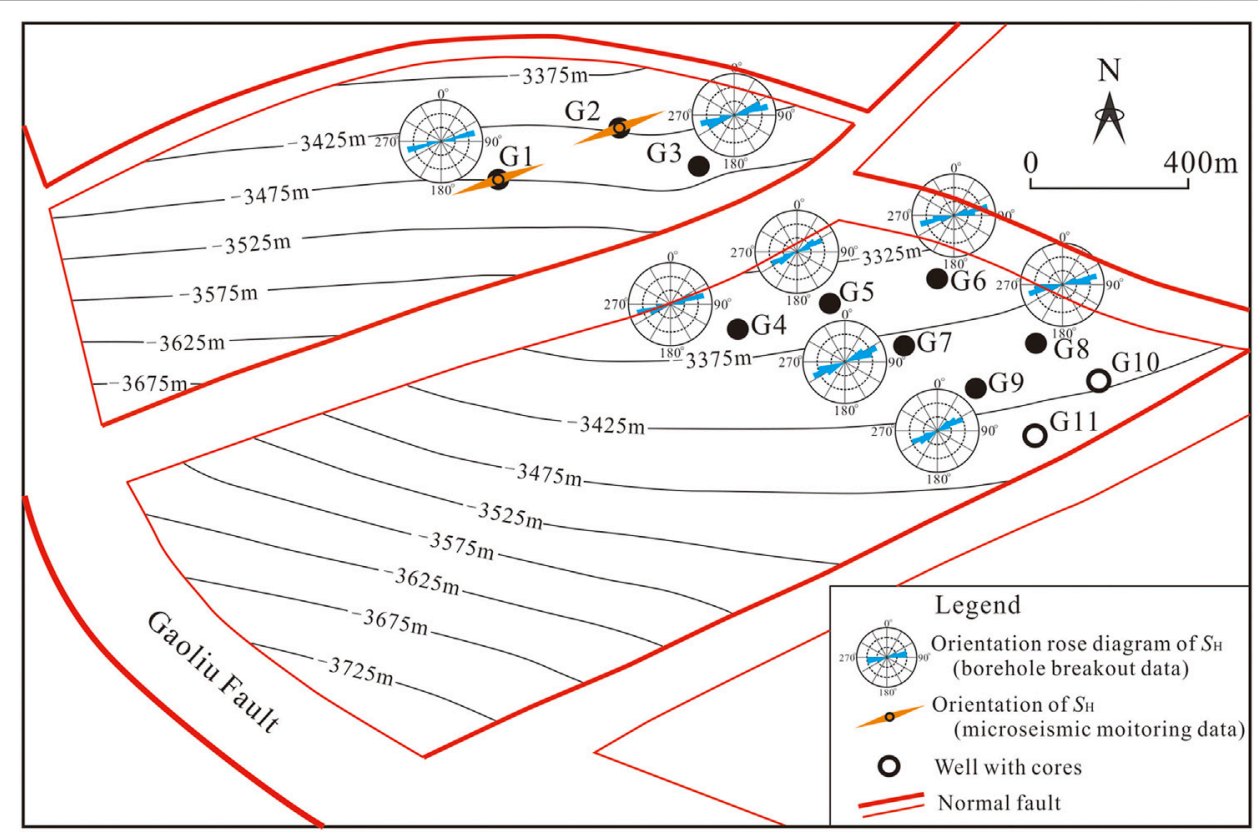

FIGURE 3 | The maximum horizontal stress $\left(S_{\mathrm{H}}\right)$ orientation of different wells. 
TABLE 1 | Characteristic parameters of samples.

\begin{tabular}{lcccccc}
\hline Sample No. & Diameter/cm & Length/cm & $\mathbf{K} / \mathbf{1 0}^{-\mathbf{3}} \mathbf{\mu \mathbf { m } ^ { \mathbf { 2 } }}$ & Depth/m & Layer & Well \\
\hline 1 & 2.512 & 5.668 & 397.7 & 3414.63 & Es 3 & G11 \\
2 & 2.522 & 5.544 & 26.3 & 3422.32 & G11 \\
3 & 2.518 & 5.487 & 15.9 & 3483.65 & Es 3
\end{tabular}

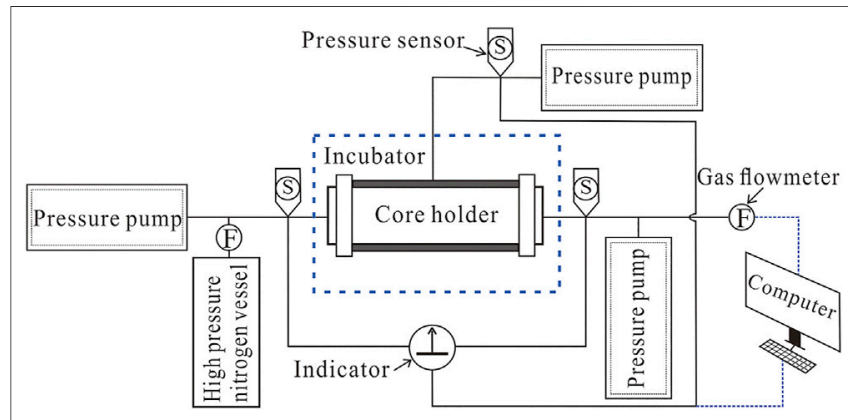

FIGURE 4 | Schematic diagram of experimental equipment.

important oil producer at Gaoshangpu Oilfield, with a thickness of $750-1,600 \mathrm{~m}(2,460.6-5,249.3 \mathrm{ft})$.

\section{Reservoir}

The Paleogene Shahejie Formation at Gaoshangpu Oilfield is characterized by a clastic deposition system dominated by fan delta deposits (Mu et al., 2003). The Sha-3 Member was deposited at fan delta front subfacies, which are dominated by underwater distributary channel sandbodies (Li et al., 2014). The reservoir is primarily medium sandstone and fine sandstone, followed by pebbly sandstone with low composition maturity and low structure maturity. The sandstones are mainly lithic feldspar sandstone and feldspar lithic sandstone, with argillaceous as matrix. The reservoir is dominated by secondary pores with average porosity and permeability of $10.3 \%$ and $11.4 \times$ $10^{-3} \mu \mathrm{m}^{2}$, respectively.

\section{In-situ Stress}

The borehole breakout method can be used to determine maximum horizontal principal stress orientation with diplog data (Collett et al., 2011) and the assumption that the long axis of the elliptical borehole is perpendicular to the maximum horizontal principal stress (Barton et al., 2013), since uneven stress can result in borehole breakout during drilling (Scelsi et al., 2019). A series of microseismic waves generated by hydraulic fracturing can be received by microseismic monitoring and can be processed to determine fracture parameters, e.g., azimuth, length, and height, where the azimuth is commonly consistent with that of maximum horizontal principal stress (Maxwell et al., 2010; Stabile et al., 2013). The dominant orientation of the maximum horizontal principal stress at Shahejie Formation is determined based on the above two methods with value of $\mathrm{N} 60^{\circ}-80^{\circ} \mathrm{E}$ (Figure 3 ).

\section{MATERIALS AND METHODS}

Core samples from three wells with a total length of $245 \mathrm{~m}(804 \mathrm{ft})$ and log data were interpreted to describe natural fractures and the orientation of maximum horizontal principal stress (Figure 1 and Figure 3). Three groups of samples were tested to analyze stress sensitivity.

Increasing effective stress or lithostatic pressure on the fracture surface due to decreasing formation pressure can lead to low fracture aperture and irreversibly decrease permeability, which is called stress-sensitivity permeability (Jelmert and Selseng, 1998). Samplings perpendicular to the formation orientation were carried out on the Paleogene sandstones. Three groups of samples were collected, namely samples with high-angle fracture (group 1), samples with micro fracture (group 2), and samples with no fracture (group 3) (Table 1). The experiment was performed on high pressure porosimeter based on singlephase flow (following Darcy's law) at room temperature to describe the stress-sensitivity fracture permeability. The equipment was mainly composed of core holder, inflator, pressure sensor, incubator, flowmeter, and a computer. (Figure 4). Fracture permeability variation with effective stress (confining pressure) was measured when loading axial pressure and keeping flow pressure. The effective stress and flow rate were assumed to be in a range of $3-40 \mathrm{MPa}$ and $0.3-0.45 \mathrm{ml} / \mathrm{min}$, respectively, based on rock-breaking test.

The variation of flow rate with pressure difference between two ends of the sample is measured through changing confining pressure under stable conditions, and thereby, the permeability can be determined based on Darcy's Law (Mackay et al., 2020).

$$
Q=K A \Delta h / L
$$

Where, $Q$ is flow rate, $L /$ min; A is cross-sectional area, $\mathrm{cm}^{2} ; \Delta h$ is pressure difference between two ends of the sample, $\mathrm{MPa}$; $L$ is length of the sample, $\mathrm{cm}$; and $\mathrm{K}$ is permeability coefficient, $\mathrm{L} / \mathrm{min}$.

Stress-sensitivity of permeability can be expressed by stress sensitive coefficient (Bustin, 1997; Hu et al., 2020), which is defined as the decreased percentage of permeability within a certain variation of boundary conditions. The stress sensitive coefficient of permeability can be expressed as (Li, 2006):

$$
I_{P}=\left(K_{o}-K_{i}\right) / K_{o}
$$

Where, $I_{P}$ is stress sensitive coefficient of permeability; $K_{i}$ is permeability under certain effective stress $\mathrm{Pi}, 10^{-3} \mu \mathrm{m}^{2}$; and $K_{o}$ is permeability under initial effective stress, $10^{-3} \mu \mathrm{m}^{2}$. 

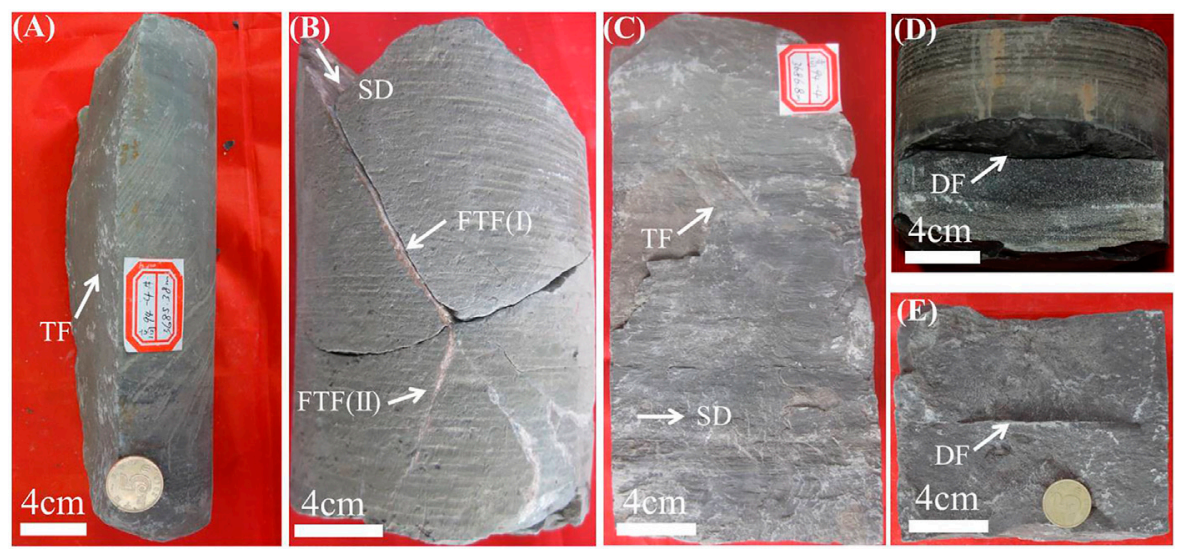

FIGURE 5 | Photos of tectonic fractures in cores of Es 3 Member (A) High dip-angle tectonic fracture. The fracture surface is smooth and flat. Well G10: depth 3,685.4 m (12,091.2 ft) (B) Two stages of fractures, set I and set II were filled with calcite, set II are terminated at set I. Well G11: depth 3,413.3 m (11,198.5 ft) (C) High dip-angle tectonic fracture. The fracture is perpendicular to the bedding planes and fracture surface shows horizontal striation. Well G10: depth 3,686.8 $\mathrm{m}$ (12,095.8 $\mathrm{ft}$ ) (D) diagenetic fracture. Well G10: depth 3,684.0 m (12,086.6 ft) (E) diagenetic fracture. Well W2: depth 3,608.6 m (11,839.2 ft). TF is tectonic fracture, DF is diagenetic fracture, TFF is filled tectonic fracture, SD is striation direction. See Figure $\mathbf{1}$ and Figure $\mathbf{3}$ for wells location.

\section{RESULTS}

\section{Core Fracture Characteristics}

Core observation suggests that fractures can be originally classified into two types in the study area: structural fractures and diagenetic fractures. Structural fractures are the most popular ones, followed by diagenetic fractures. The structural fractures are dominated by shear ones with an average linear density of $1.3 \mathrm{~m}^{-1}$. These fractures have straight and smooth surfaces and large penetration (Figure 5A). Two-stage fractures can be observed, while fractures at the early stage limit fracture extension at the late stage (Figure 5B). Also, two types of scorings can be found from fracture surface. The orientation of the first type is the same as the inclination of fracture surface (Figure 5B), while that of the second type, the popular one in the study area, is the same as the orientation of fracture surface (Figure 5C). It indicates a significant difference between their development conditions, i.e., the former was attributed to tensile
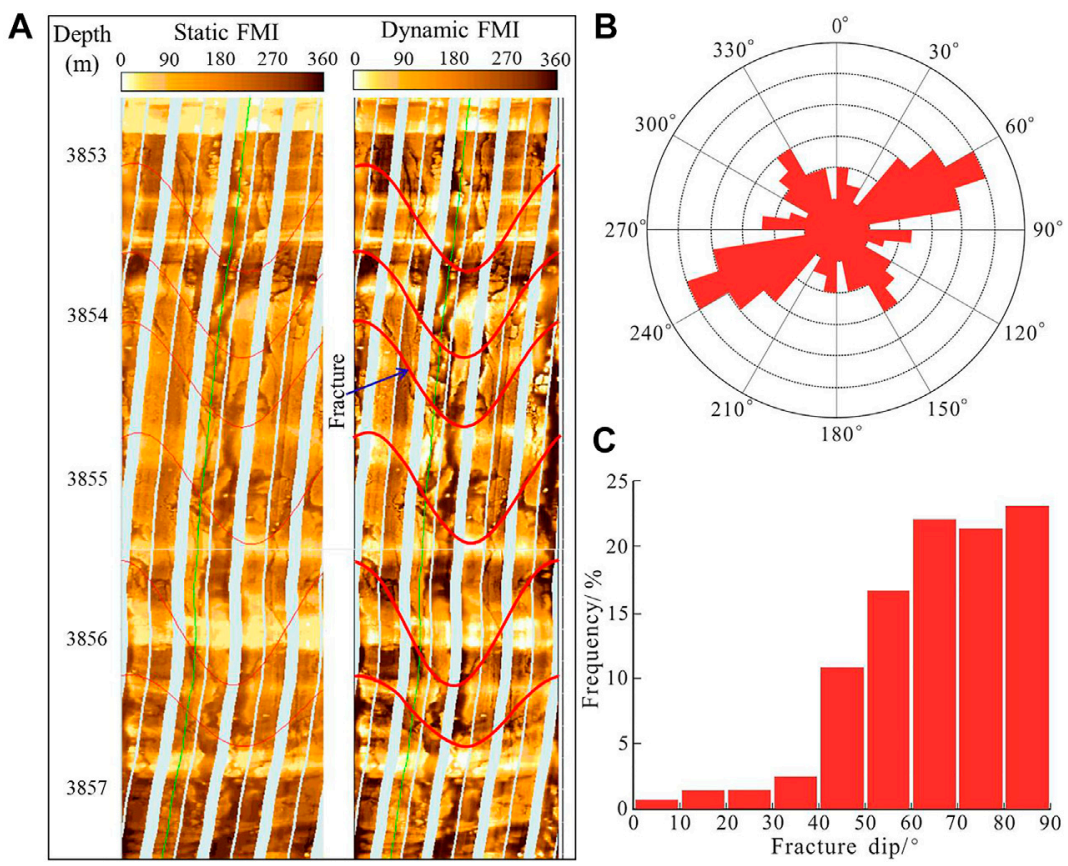

FIGURE 6 | Parameters of natural fractures (A) Fractures detected by formation microscanner image (FMI) in well W1 (B) Rose diagrams of natural fracture strike from FMl in the Paleogene sandstones $(N=161)$ (C) Dip of natural fracture from FMl and cores in the Paleogene sandstones $(N=297)$. See Figure 1 for well W1 location. 


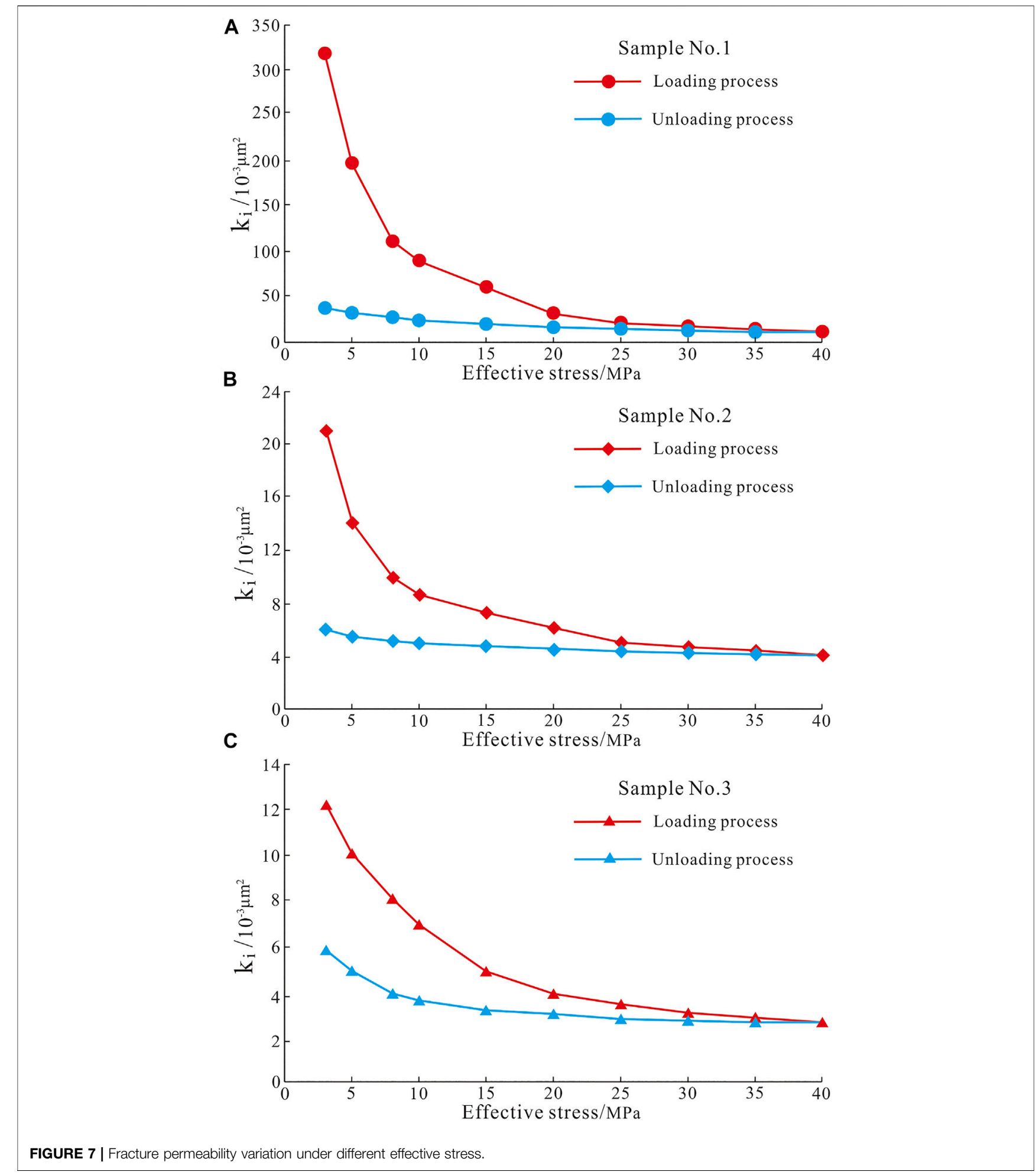

stress, while the latter was caused by strike-slip tectonic stress. Some fractures are filled by calcite, e.g., the partly-filled and fullyfilled fractures account for 6.7 and $7.5 \%$, respectively. while lowfilling indicates high fracture valid. Diagenetic fractures are mainly developed in argillaceous rocks with low fracture density (average value of $0.3 \mathrm{~m}^{-1}$ ), which are mainly low-angle fractures $\left(<30^{\circ}\right)$ (Figures 5D,E). Such fractures have small apertures and poor permeability under overlying pressure, exerting only a minor impact on oil and gas development (Zeng et al., 2010). 


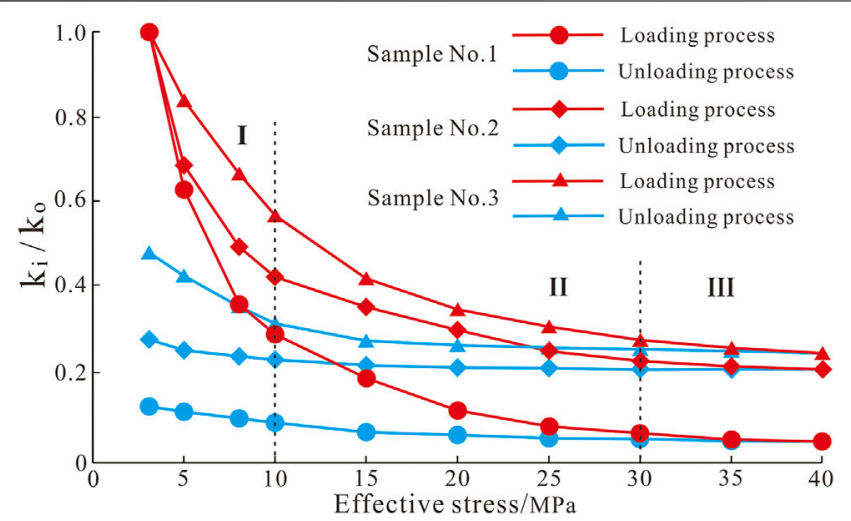

FIGURE $\mathbf{8}$ | Contrast chart of unitary experimental data of different samples.

\section{FMI Fracture Characteristics}

FMI log is an important approach to identify natural fractures (Genter et al., 1997; Jiu et al., 2013). Natural fractures are represented by a complete sinusoidal curve (Figure 6A) on FMI, where dark sinusoidal curves represent effective fractures due to low resistance (mud filtrate invasion), and light sinusoidal curves express filling fractures (Niu et al., 2008). Two groups of fractures can be identified from FMI in the study area, i.e., NE-SW strike fractures (with proportion of $45.9 \%$, density of $1.0 \mathrm{~m}^{-1}$, filling degree of $9.3 \%$ ) and NWSE strike fractures (with proportion of $28.1 \%$, density of $0.6 \mathrm{~m}^{-1}$, filling degree of $\left.11.4 \%\right)$. Also, two groups of secondary fractures can be found: E-W strike and S-N strike fractures (Figure 6B). The dip angle primarily varies between $60-90^{\circ}$ with a small group of low-angle fractures (Figure 6C).

\section{Fracture Permeability Stress-Sensitivity}

Measurements on three groups of samples show that permeability has a negative exponential correlation with increasing effective stress, which is poorly recovered with decreasing effective stress (Figure 7). The permeability of these samples share a similar variation trend, but have some differences in variation amplitude. The permeability of group 1 and group 2 samples decreases rapidly at the initial stage (with effective stress of 3-10 MPa). After that, it decreases slowly with confining pressure at $10-30 \mathrm{MPa}$, which is obvious in group 2 samples. Finally, it decreases slightly when the effective stress reaches $30 \mathrm{MPa}$ (Figures 7A,B). In terms of the group 3 samples, the permeability also decreases rapidly at the initial stage, but has smaller decreased amplitude compared with the group 1 and group 2 samples. Its permeability can be well recovered with decreasing effective stress (Figure 7C). The stress sensitive coefficients of permeability are 0.894, 0.733, and 0.518, respectively, for these three groups. Consequently, the group 1 and group 2 samples have intensive stresssensitivity permeability, and the group 3 samples have a medium one, according to the criterion proposed by $\mathrm{Li}$ (2006).

\section{DISCUSSION}

Mechanical mechanisms of structural fracture growth (Olsson et al., 2004; Gale and Gomez, 2007; Zhang et al., 2020) suggests that tensile stress field occurs when the orientation of the scoring is consistent with the inclination of fracture surface [where the maximum principal stress $\left(\sigma_{1}\right)$ is vertical and the intermediate principal stress $\left(\sigma_{2}\right)$ and the minimum principal stress $\left(\sigma_{3}\right)$ are horizontal], and it is consistent with the tensile stress field at the late Paleogene of Nanpu Sag (Tong et al., 2013), where NE-SW horizontal compression and NW-SE tensile stress developed NESW direction shear fractures. Strike-slip tectonic stress occurs when the scoring shares the same orientation with fracture surface (where the $\sigma_{2}$ is vertical, the $\sigma_{1}$ and $\sigma_{3}$ are horizontal). Hence, it corresponds to the strike-slip tectonic stress field at the end of Neogene (Fan et al., 2010; Jiang et al., 2015), where the near E-W horizontal compression resulted in the NE-SW and NW-SE directions' structural fractures. Combined with the fracture pattern (Figure 5), these structural fractures in the study area can be determined to have been formed during the late Paleogene and late Neogene.

The stress-sensitivity permeability can be divided into three phases based on variation amplitude (Figure 8). In terms of the group 1 samples, the ratio of average amplitudes for three phases is about $4: 2: 1$. Natural fracture, the primary seepage channel, decreases sharply in apertures with increasing effective stress at phase I. It results in a rapid decrease in permeability, which can be explained by the exponential relationship between fracture aperture and permeability (Alnoaimi and Kovscek, 2019). After that, the permeability decreases smoothly with slowly decreased fracture apertures. High effective stress falls off particles attached to the pore surface at phase III, which can plug narrow throats or pores and decrease matrix permeability (Jones et al., 2001; Zhang et al., 2015; Geng et al., 2017). The stress sensitive coefficient of group 2 basically shares the same variation trend and origin with group 1, who has a smaller variation amplitude (about 2.2:1.3:1). The ratio of average variation amplitude of stress sensitive coefficient in matrix rock is about 1.8:1.2:1, which is the lowest due to the increased stress sensitive coefficient involving fracture closure (Warpinski and Teufel, 
1992; Zhang et al., 2019). Large throats in matrix rock, as main seepage channels, are typically the first to be narrowed with increasing effective stress, rapidly decreasing permeability. The remaining small throats and pores are difficult to be further closed and deformed when the rock sample is compressed to a certain degree, which can explain the slow decrease in permeability (Magdalena and Erling, 2013; Gowacki and Selvadurai, 2016). Hence, the stress-sensitivity permeability is closely related to fracture aperture and throat size.

Fractures govern well patterns in low-permeability oilfields through controlling the seepage system (Tamagawa and Pollard, 2008; Laubach et al., 2018). Fracture permeability varies as a function of fracture density, filling degree, and current in-situ stress (Baytok and Pranter, 2013; Gong et al., 2019b; Wang Z. et al., 2020). The NE-SW strike fractures in the study area are characterized by their high density, large aperture, being weaklyfilled, and approximately parallel to the regional maximum horizontal principal stress (Connolly and Cosgrove, 1999). Therefore, these fractures have high permeability and are the dominant seepage system at the early development stage. However, flow velocity at these fractures is high and pressure drops sharply at the early stage, and fracture apertures and permeability also decrease at a high speed. The occurrence of stress-sensitivity decreases permeability of fractured reservoirs significantly at the Gaoshangpu Oilfield, which leads to high injection pressure when transferring into water flooding under the existing well pattern. Therefore, it is necessary to minimize the negative influence of stress sensitivity via maintaining formation energy and original pressure-seepage field. NW-SE strike fractures, secondary seepage system at the early stage, are slow in aperture decreasing and permeability declining, which works better in fluid flowing compared with other fractures. This can be confirmed by the well-connected injectors and producers along the NW-SE direction. Therefore, it is necessary to regulate well pattern based on fracture dynamic parameters at different stages, which is important to improve the performance of low-permeability fractured reservoirs.

\section{CONCLUSION}

Shear fractures in Paleogene sandstone reservoirs at Nanpu Sag chiefly assume the NE-SW direction; the second most common are

\section{REFERENCES}

Abul Khair, H., Cooke, D., and Hand, M. (2015). Paleo Stress Contribution to Fault and Natural Fracture Distribution in the Cooper Basin. J. Struct. Geology 79, 31-41. doi:10.1016/j.jsg.2015.07.007

Alhuraishawy, A. K., Bai, B., Wei, M., Geng, J., and Pu, J. (2018). Mineral Dissolution and fine Migration Effect on Oil Recovery Factor by Low-Salinity Water Flooding in LowPermeability sandstone Reservoir. Fuel 220, 898-907. doi:10.1016/j.fuel.2018.02.016

Alnoaimi, K. R., and Kovscek, A. R. (2019). Influence of Microcracks on Flow and Storage Capacities of Gas Shales at Core Scale. Transp Porous Med. 127, 53-84. doi:10.1007/s11242-018-1180-5

Babadagli, T. (2020). Unravelling Transport in Complex Natural Fractures with Fractal Geometry: A Comprehensive Review and New Insights. J. Hydrol. 587, 124937. doi:10.1016/j.jhydrol.2020.124937 the fractures of the NW-SE direction. They were formed due to tensile stress in the late Paleogene and the strike-slip stress at the late Neogene. The permeability is medium stress-sensitivity in matrix, but is intensive stress-sensitivity in fractures. The variation of permeability with increasing effective stress can be divided into three phases, which are closely related to fracture aperture and throat size. Therefore, paying attention to fracture dynamic parameters and adjusting corresponding well patterns is important to improving the performance of fractured reservoirs at different development stages.

\section{DATA AVAILABILITY STATEMENT}

The original contributions presented in the study are included in the article/supplementary materials, further inquiries can be directed to the corresponding author.

\section{AUTHOR CONTRIBUTIONS}

ZW: Methodology, Investigation, Writing - Original Draft; MM: Conceptualization; DX: Experiment; JF: Resources, Software; JL: Visualization, Data Curation; ZZ: Methodology, Funding acquisition; DL: Resources, Software; LG: Data Curation.

\section{FUNDING}

This study is financially supported by the National Natural Science Foundation of China (No: 41172015) and the National Major Science and Technology Projects of China (2017ZX05009001-002).

\section{ACKNOWLEDGMENTS}

The authors wish to thank Haigang Lao, doctor of China University of Petroleum (Huadong), for his sincere and generous help. This study is financially supported by the National Natural Science Foundation of China (No: 41172015) and the National Major Science and Technology Projects of China (2017ZX05009001-002).

Barton, C. A., Zoback, M. D., and Burns, K. L. (2013). In-Situ Stress Orientation and Magnitude at the Fenton Geothermal Site, New Mexico, Determined from Wellbore Breakouts. Geophys. Res. Lett. 15 (5), 467-470. doi:10.1029/ GL015i005p00467

Baytok, S., and Pranter, M. J. (2013). Fault and Fracture Distribution within a Tight-Gas sandstone Reservoir: Mesaverde Group, Mamm Creek Field, Piceance Basin, Colorado, USA. Pet. Geosci. 19 (3), 203-222. doi:10.1144/ petgeo2011-093

Cao, D., Wang, A., Ning, S., Li, H., Guo, A., Chen, L., et al. (2020). Coalfield Structure and Structural Controls on Coal in China. Int. J. Coal. Sci. Technol. 7 (2), 220-239. doi:10.1007/s40789-020-00326-z10.1007/s40789-020-00326-z

Collett, T. S., Lewis, R. E., Winters, W. J., Lee, M. W., Rose, K. K., and Boswell, R. M. (2011). Downhole Well Log and Core Montages from the Mount Elbert Gas Hydrate Stratigraphic Test Well, Alaska North Slope. Mar. Pet. Geology 28, 561-577. doi:10.1016/j.marpetgeo.2010.03.016 
Dong, Y., Xiao, L., Zhou, H., Wang, C., Zheng, J., Zhang, N., et al. (2010). The Tertiary Evolution of the Prolific Nanpu Sag of Bohai bay basin, china: Constraints from Volcanic Records and Tectono-Stratigraphic Sequences. Geol. Soc. America Bull. 122, 609-626. doi:10.1130/B30041.1

Fan, B. J., Liu, C. L., Liu, G. D., and Zhu, J. (2010). Forming Mechanism of the Fault Systerm and Structural Evolution History of Nanpu Sag. J. Xi,an Shiyou University(Natural Sci. Edition) 25, 13-20. (in Chinese with English abstract).

Gale, J. F. W., and Gomez, L. A. (2007). Late Opening-Mode Fractures in KarstBrecciated Dolostones of the Lower Ordovician Ellenburger Group, West texas: Recognition, Characterization, and Implications for Fluid Flow. Bulletin 91, 1005-1023. doi:10.1306/03130706066

Geng, Y., Tang, D., Xu, H., Tao, S., Tang, S., Ma, L., et al. (2017). Experimental Study on Permeability Stress Sensitivity of Reconstituted Granular Coal with Different Lithotypes. Fuel 202, 12-22. doi:10.1016/j.fuel.2017.03.093

Genter, A., Castaing, C., Dezayes, C., Tenzer, H., Traineau, H., and Villemin, T. (1997). Comparative Analysis of Direct (Core) and Indirect (Borehole Imaging Tools) Collection of Fracture Data in the Hot Dry Rock Soultz Reservoir (france). J. Geophys. Res. 102, 15419-15431. doi:10.1029/97jb00626

Gong, L., Fu, X., Wang, Z., Gao, S., Jabbari, H., Yue, W., et al. (2019b). A New Approach for Characterization and Prediction of Natural Fracture Occurrence in Tight Oil Sandstones with Intense Anisotropy. Bulletin 103, 1383-1400. doi:10.1306/12131818054

Gong, L., Su, X., Gao, S., Fu, X., Jabbari, H., Wang, X., et al. (2019a). Characteristics and Formation Mechanism of Natural Fractures in the Tight Gas Sandstones of Jiulongshan Gas Field, China. J. Pet. Sci. Eng. 175, 1112-1121. doi:10.1016/ j.petrol.2019.01.021

Gong, L., Wang, J., Gao, S., Fu, X., Liu, B., Miao, F., et al. (2021). Characterization, Controlling Factors and Evolution of Fracture Effectiveness in Shale Oil Reservoirs. J. Pet. Sci. Eng. 203, 108655. doi:10.1016/j.petrol.2021.108655

Gowacki, A., and Selvadurai, A. P. S. (2016). Stress-induced Permeability Changes in indiana limestone. Eng. Geol. 215, 122-130. doi:10.1016/ j.enggeo.2016.10.015

Hu, Z., Klaver, J., Schmatz, J., Dewanckele, J., Littke, R., Krooss, B. M., et al. (2020). Stress Sensitivity of Porosity and Permeability of Cobourg limestone. Eng. Geology 273, 105632. doi:10.1016/j.enggeo.2020.105632

Jelmert, T. A., and Selseng, H. (1998). Permeability Function Describes Core Permeability in Stress-Sensitive Rocks. Oil Gas J. 96 (49), 60-63. doi:10.1016/ S1353-2561(99)00081-X

Jiang, F., Pang, X., Li, L., Wang, Q., Dong, Y., Hu, T., et al. (2018). Petroleum Resources in the Nanpu Sag, Bohai Bay Basin, Eastern China. Bulletin 102, 1213-1237. doi:10.1306/0906171608017148

Jiang, Y. L., Liu, P., Song, G. Q., Liu, H., Wang, Y. S., and Zhao, K. (2015). Late Cenozoic Faulting Activities and Their Influence upon Hydrocarbon Accumulations in the Neogene in Bohai Bay Basin. Oil Gas Geology 36 (4), 525-533. doi:10.11743/ogg20150401

Jiu, K., Ding, W., Huang, W., Zhang, Y., Zhao, S., and Hu, L. (2013). Fractures of Lacustrine Shale Reservoirs, the Zhanhua Depression in the Bohai bay basin, Eastern china. Mar. Pet. Geology 48, 113-123. doi:10.1016/ j.marpetgeo.2013.08.009

Jones, C., Somerville, J. M., Smart, B. G. D., Kirstetter, O., Hamilton, S. A., and Edlmann, K. P. (2001). Permeability Prediction Using Stress Sensitive Petrophysical Properties. Pet. Geosci. 7, 211-219. doi:10.1144/petgeo.7.2.211

Laubach, S. E., Lamarche, J., Gauthier, B. D. M., Dunne, W. M., and Sanderson, D. J. (2018). Spatial Arrangement of Faults and Opening-Mode Fractures. J. Struct. Geology 108, 2-15. doi:10.1016/j.jsg.2017.08.008

Li, C. L. (2006). Evaluation Method for Stress Sensitivity of Reservoir Rock. Pet. Geology. Oil Field Develop. Daqing 25 (1), 40-43. (in Chinese with English abstract).

Li, J., Li, X.-R., Song, M.-S., Liu, H.-M., Feng, Y.-C., and Liu, C. (2021). Investigating Microscopic Seepage Characteristics and Fracture Effectiveness of Tight Sandstones: a Digital Core Approach. Pet. Sci. 18, 173-182. doi:10.1007/s12182-020-00464-8

Li, Y. H., Qi, L. X., Xia, Q. J., Yang, J. X., Chen, S. Y., and Cao, T. F. (2014). Reservoir Characteristics of $\mathrm{Es}_{3}{ }^{3}$ in Gaoshangpu Oilfield. China Mining Mag. 23 (9), 83-88. (in Chinese with English abstract).

Lin, K., Huang, W., Finkelman, R. B., Chen, J., Yi, S., Cui, X., et al. (2020). Distribution, Modes of Occurrence, and Main Factors Influencing lead
Enrichment in Chinese Coals. Int. J. Coal. Sci. Technol. 7 (1), 1-18. doi:10.1007/s40789-019-00292-1

Liu, B., Yang, Y., Li, J., Chi, Y., Li, J., and Fu, X. (2020). Stress Sensitivity of Tight Reservoirs and its Effect on Oil Saturation: A Case Study of Lower Cretaceous Tight Clastic Reservoirs in the Hailar Basin, Northeast China. J. Pet. Sci. Eng. 184, 106484. doi:10.1016/j.petrol.2019.106484

Mackay, F., Toner, J., Morozov, A., and Marenduzzo, D. (2020). Darcy's Law without Friction in Active Nematic Rheology. Phys. Rev. Lett. 124 (18), 187801. doi:10.1103/PhysRevLett.124.187801

Maxwell, S. C., Rutledge, J., Jones, R., and Fehler, M. (2010). Petroleum Reservoir Characterization Using Downhole Microseismic Monitoring. Geophysics 75 (5), 75A129-75A137. doi:10.1190/1.3477966

Mu, L. H., Peng, S. M, Yin, Z. J., and Lei, Y. L. (2003). Sequence Stratigraphy and Lithofacies Palaeography of the Shahejie Formation of Paleogene in Liuzan Oilfield, Eastern Hebei Province. J. Palaeogeogr. 5 (3), 304-315.

Nagel, N. B., Sanchez-Nagel, M. A., Zhang, F., Garcia, X., and Lee, B. (2013). Coupled Numerical Evaluations of the Geomechanical Interactions between a Hydraulic Fracture Stimulation and a Natural Fracture System in Shale Formations. Rock Mech. Rock Eng. 46 (3), 581-609. doi:10.1007/s00603-013-0391-x

Niu, H. L., Tian, Z. J., Hu, X., and Zhuang, S. (2008). Application of Imaging Log Interpretation Patterns in Fractured Basement Reservoirs. Prog. Geophys. 23 (5), 1544-1549. doi:10.1016/S1872-5791(08)60056-1

Olorode, O. M., Freeman, C. M., Moridis, G. J., and Blasingame, T. A. (2012). HighResolution Numerical Modeling of Complex and Irregular Fracture Patterns in Shale Gas and Tight Gas Reservoirs. SPE Reserv. Eval. Eng. 16, 443-455. doi:10.2118/152482-MS

Olsson, W. A., Lorenz, J. C., and Cooper, S. P. (2004). A Mechanical Model for Multiply-Oriented Conjugate Deformation Bands. J. Struct. Geology 26, 325-338. doi:10.1016/s0191-8141(03)00101-9

Pang, B., Dong, Y. X., Chen, D., and Pang, X. Q. (2019). Main Controlling Factors and Basic Model for Hydrocarbon Enrichment in the sandstone Target Layer of Petroliferous basin: a Case Study of Neogene sandstone Reservoirs in Nanpu Sag, Bohai Bay Basin. Acta Petrolei Sinica 40 (5), 519-531. doi:10.7623/ syxb201905002

Connolly, P., and Cosgrove, J. (1999). Prediction of Fracture-Induced Permeability and Fluid Flow in the Crust Using Experimental Stress Data. Bulletin 83, 757-777. doi:10.1306/e4fd2d75-1732-11d7-8645000102c1865d

Qing, F., Yan, J., Wang, J., Hu, Q., Wang, M., Geng, B., et al. (2021). Pore Structure and Fluid Saturation of Near-Oil Source Low-Permeability Turbidite sandstone of the Dongying Sag in the Bohai Bay Basin, east China. J. Pet. Sci. Eng. 196, 108106. doi:10.1016/j.petrol.2020.108106

Bustin, R. M. (1997). Importance of Fabric and Composition on The Stress Sensitivity of Permeability in Some Coals, Northern Sydney Basin, Australia: Relevance To Coalbed Methane Exploitation. Bulletin 81, 1894-1908. doi:10.1306/3B05C65E-172A-11D7-8645000102C1865D

Scelsi, G., De Bellis, M. L., Pandolfi, A., Musso, G., and Della Vecchia, G. (2019). A Step-by-step Analytical Procedure to Estimate the In-Situ Stress State from Borehole Data. J. Pet. Sci. Eng. 176, 994-1007. doi:10.1016/j.petrol.2019.01.100

Shanley, K. W., and Cluff, R. M. (2015). The Evolution of Pore-Scale FluidSaturation in Low-Permeability sandstone Reservoirs. Bulletin 99, 1957-1990. doi:10.1306/03041411168

Stabile, T. A., Iannaccone, G., Zollo, A., Lomax, A., Ferulano, M. F., Vetri, M. L. V., et al. (2013). A Comprehensive Approach for Evaluating Network Performance in Surface and Borehole Seismic Monitoring. Geophys. J. Int. 192, 793-806. doi:10.1093/gji/ggs049

Stroisz, A. M., and Fjær, E. (2013). Tracing Causes for the Stress Sensitivity of Elastic Wave Velocities in Dry Castlegate sandstone. Geophys. J. Int. 192 (1), 137-147. doi:10.1093/gji/ggs029

Tamagawa, T., and Pollard, D. D. (2008). Fracture Permeability Created by Perturbed Stress Fields Around Active Faults in a Fractured Basement Reservoir. Bulletin 92, 743-764. doi:10.1306/02050807013

Tong, H. M., Zhao, B. Y., Cao, Z., Liu, G. X., Dun, X. M., and Zhao, D. (2013). Structural Analysis of Faulting System Origin in the Nanpu Sag, Bohai Bay Basin. Acta Geologica Sinica 87 (11), 1647-1661.

Wang, Z. S., Dong, S. Q., Meng, N. N., Liu, D. J., and Gao, W. (2020a). Fracture Network and its Controlling Factors in the Low-Permeable Fault Block Reservoirs in Deep-Buried Gaoshangpu Oilfield, Bohai Bay Basin. Oil Gas Geology 41 (3), 534-542. doi:10.11743/ogg20200310 
Wang, Z., Zeng, L., Luo, Z., Zu, K., Lao, H., and Meng, N. (2020b). Natural Fractures in the Triassic Tight Sandstones of the Dongpu Depression, Bohai Bay Basin, Eastern China: The Key to Production. Interpretation 8 (4), SP71-SP80. doi:10.1190/INT-2019-0252.1

Warpinski, N. R., and Teufel, L. W. (1992). Determination of the Effective-Stress Law for Permeability and Deformation in Low-Permeability Rocks. SPE Formation Eval. 7 (2), 123-131. doi:10.2118/20572-PA

Zeng, L., Jiang, J., and Yang, Y. (2010). Fractures in the Low Porosity and UltraLow Permeability Glutenite Reservoirs: A Case Study of the Late Eocene Hetaoyuan Formation in the Anpeng Oilfield, Nanxiang Basin, China. Mar. Pet. Geology 27, 1642-1650. doi:10.1016/j.marpetgeo.2010.03.009

Zeng, L., Lyu, W., Li, J., Zhu, L., Weng, J., Yue, F., et al. (2016). Natural Fractures and Their Influence on Shale Gas Enrichment in Sichuan Basin, China. J. Nat. Gas Sci. Eng. 30, 1-9. doi:10.1016/j.jngse.2015.11.048

Zeng, L., Su, H., Tang, X., Peng, Y., and Gong, L. (2013). Fractured Tight sandstone Oil and Gas Reservoirs: A New Play Type in the Dongpu Depression, Bohai Bay Basin, China. Bulletin 97, 363-377. doi:10.1306/O912121205710.1306/09121212057

Zeng, L., Tang, X., Wang, T., and Gong, L. (2012). The Influence of Fracture Cements in Tight Paleogene saline Lacustrine Carbonate Reservoirs, Western Qaidam Basin, Northwest China. Bulletin 96, 2003-2017. doi:10.1306/04181211090

Zhang, F., An, M., Zhang, L., Fang, Y., and Elsworth, D. (2020). Effect of Mineralogy on Friction-Dilation Relationships for Simulated Faults: Implications for Permeability Evolution in Caprock Faults. Geosci. Front. 11 (2), 439-450. doi:10.1016/j.gsf.2019.05.014

Zhang, H. Y., He, S. L., Luan, G. H., Men, C. Q., Mo, S. Y., and Liu, H. (2015). Experimental Study on Stress Sensitivity of Microfracture Ultra-low Permeability Reservoirs. J. Xi'an Shiyou University( Nat. Sci. Edition) 30 (1), 30-35. doi:10.3969/j.issn.1673-064X.2015.01.005

Zhang, J., Li, Y., Pan, Y., Wang, X., Yan, M., Shi, X., et al. (2021). Experiments and Analysis on the Influence of Multiple Closed Cemented Natural Fractures on Hydraulic Fracture Propagation in a Tight sandstone Reservoir. Eng. Geology 281, 105981. doi:10.1016/j.enggeo.2020.105981
Zhang, J., Wei, C., Ju, W., Yan, G., Lu, G., Hou, X., et al. (2019). Stress Sensitivity Characterization and Heterogeneous Variation of the Pore-Fracture System in Middle-High Rank Coals Reservoir Based on Nmr Experiments. Fuel 238, 331-344. doi:10.1016/j.fuel.2018.10.127

Zhang, K., Jiang, S. H., Yue, J. T., Wang, Y. Y., and Wang, Y. F. (2018). Sedimentary Micro-Facies of Fan Delta in $\mathrm{Es}_{3}{ }^{2+3}$ Submember, Gaoshangpu Oilfield. Periodical Ocean Univ. China 48 (5), 86-94. doi:10.16441/J.cnki.hdxb.20160377

Zhao, X. X., Zhou, L., Pu, X., Jin, F., Shi, Z., Han, W., et al. (2020). Formation Conditions and Enrichment Model of Retained Petroleum in Lacustrine Shale: A Case Study of the Paleogene in Huanghua Depression, Bohai Bay Basin, Chinan. Pet. Exploration Develop. 47 (5), 916-930. doi:10.1016/S1876-3804(20)60106-9

Conflict of Interest: MM, DX, JF and JL are employed by CNPC Logging Company Limited Xinjiang Branch. DL is employed by CNPC Jidong Oilfield.

The remaining authors declare that the research was conducted in the absence of any commercial or financial relationships that could be construed as a potential conflict of interest.

Publisher's Note: All claims expressed in this article are solely those of the authors and do not necessarily represent those of their affiliated organizations, or those of the publisher, the editors and the reviewers. Any product that may be evaluated in this article, or claim that may be made by its manufacturer, is not guaranteed or endorsed by the publisher.

Copyright (c) 2021 Wang, Muhtar, Xu, Fang, Li, Liu, Zhang and Gao. This is an open-access article distributed under the terms of the Creative Commons Attribution License (CC BY). The use, distribution or reproduction in other forums is permitted, provided the original author(s) and the copyright owner(s) are credited and that the original publication in this journal is cited, in accordance with accepted academic practice. No use, distribution or reproduction is permitted which does not comply with these terms. 